\title{
Report on Three Patients with Blastic Plasmacytoid Dendritic Cell Neoplasm
}

\author{
Blastik Plazmasitoid Dentritik Hücreli Neoplazmlı Üç Olgu Sunumu
}

\author{
(D) Hale Bülbül ${ }^{1}$, (D) Nazan Özsan², (D) Mine Hekimgil2 , (D) Güray Saydam¹, (D) Mahmut Töbü ${ }^{1}$ \\ ${ }^{1}$ Ege University Faculty of Medicine Hospital, Department of Internal Medicine, Division of Hematology, Izmir, Turkey \\ ${ }^{2}$ Ege University Faculty of Medicine Hospital, Department of Pathology, Izmir, Turkey
}

To the Editor,

Blastic plasmacytoid dendritic cell neoplasm (BPDCN) is a rare, clinically aggressive tumor that was classified as a distinct entity among myeloid neoplasms in the World Health Organization's 2016 revision of the classification of acute myeloid leukemia and related neoplasms. Most patients present with cutaneous lesions with or without bone marrow involvement and leukemic dissemination. The tumor cells express CD4, CD56, CD123, and TCL1 [1]. In general, acute lymphocytic leukemia (ALL)/ lymphoma-type regimens were reported to show better survival outcomes than acute myeloid leukemia (AML)-type regimens. Complete remissions were registered for 7 of 26 patients after AML-type regimens and 10 of 15 patients after ALL/lymphomatype regimens, with a significant advantage for the ALL/ lymphoma-type approach $[2,3]$. Patients who were treated with hyper-CVAD showed an objective response, but the duration of response was short so hematopoietic stem cell transplantation (HSCT) should also be considered [4]. Recent interest has been directed towards SL-401, a novel immunotherapy directed at IL-3R, notably overexpressed in BPDCN as well as other myeloid malignancies. This led to the development of SL-401 as an IL3-diphtheria toxin conjugate that has demonstrated promise for BPDCN in early-phase trials $[5,6,7,8]$. We aim to share our experience with BPDCN due to its rareness and the lack of a consensus about treatment.

All three patients were male, aged 19, 55, and 65 years, and were admitted to the hospital with fever, weight loss, weakness, and lymphadenopathy. Physical examination revealed that all of them had lymphadenopathies, one of them had hepatosplenomegaly, and two of them had skin lesions. Skin lesions were bruise-like brown to violaceous infiltrated plaques on the back and extremities. One patient had a brown-purple tumoral mass and also brown-purple nodular lesions of the head region (Figure 1). Bone marrow and lymph node biopsies showed diffuse infiltration by medium-sized blasts with irregular nuclear contour, slightly large cytoplasm, high mitotic index, and immunohistochemical expression of CD4+, CD56+, CD123+, and TCL1+. Skin biopsies revealed diffuse infiltration by similar cells. One patient had central nervous system involvement that was pathologically proven by cerebrospinal fluid cytology. In one patient's bone marrow results, 36\% TCF3 and 35\% TEL gene deletions were detected by hybridization. A hyperCVAD regimen was initiated for all patients. After one cycle of chemotherapy, two patients achieved complete remission (CR). One patient who achieved $C R$ and the patient who could not achieve CR died of sepsis. The other patient who achieved CR after one course of chemotherapy was treated with three cycles of the hyper-CVAD regimen as maintenance and afterwards he underwent transplantation with peripheral blood progenitor cells from a related mismatched donor. BuCy was administered for the conditioning regimen before transplantation.

Two patients achieved CR with the hyper-CVAD regimen and one of them who underwent allogenic transplantation is still in CR 18 months after diagnosis. BPDCN can go into durable remission with HSCT regardless of the type of the induction regimen. In particular, auto-HSCT in first CR appears to be a reasonable treatment option and may play an important role in improving the outcomes of BPDCN [9]. On the other hand, high-dose therapy followed by allo-HSCT can provide durable disease control in up to $50 \%$ of patients and allo-HSCT should be administered in first CR if possible [10]. Allogeneic stem cell transplantation seems to improve the prognosis, but further studies are needed to confirm the place and the indication of this treatment strategy.
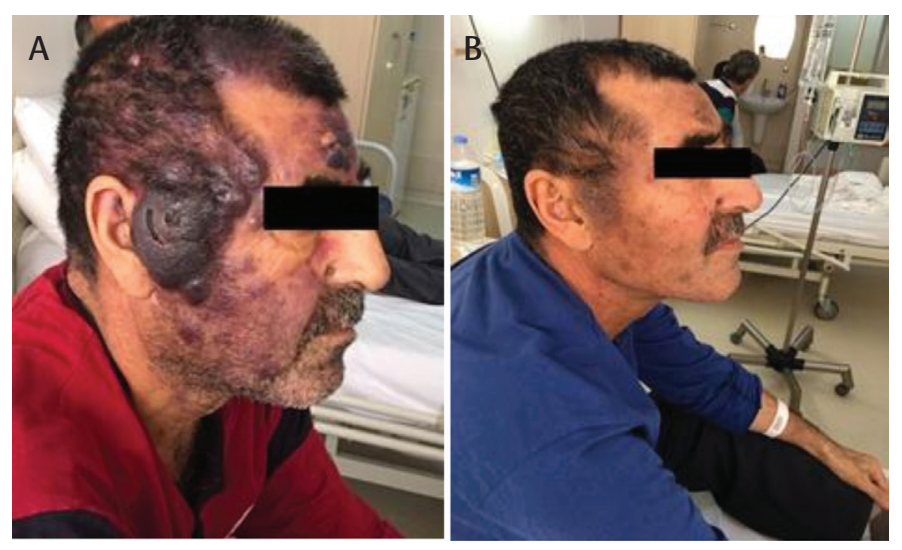

Figure 1. Brown-purple tumoral mass of $3 \times 3 \mathrm{~cm}$ in diameter on the right temporal region (A). After a single cycle of chemotherapy, skin lesions regressed (B). 
Keywords: Blastic plazmositoid dentritic cell neoplasm, HyperCVAD regimen, Stem cell transplantation

Anahtar Sözcükler: Blastik plazmositoid dentritik hücreli neoplazi, HyperCVAD rejimi, Kök hücre nakli

Informed Consent: In this case presentation, two of the three patients had died. Informed consent was received from the third living patient.

Conflict of Interest: The authors of this paper have no conflicts of interest, including specific financial interests, relationships, and/or affiliations relevant to the subject matter or materials included.

\section{References}

1. Feuillard J, Jacob MC, Valensi F, Maynadié M, Gressin R, Chaperot L, Arnoulet C, Brignole-Baudouin F, Drénou B, Duchayne $E$, Falkenrodt A, Garand $R$, Homolle $E$, Husson B, Kuhlein E, Le Calvez G, Sainty D, Sotto MF, Trimoreau $\mathrm{F}$, Béné MC. Clinical and biologic features of $\mathrm{CD} 4^{+} \mathrm{CD} 56^{+}$malignancies. Blood 2002;99:1556-1563.

2. Pagano L, Valentini CG, Pulsoni $A$, Fisogni $S$, Carluccio $P$, Mannelli $F$, Lunghi M, Pica G, Onida F, Cattaneo C, Piccaluga PP, Di Bona E, Todisco E, Musto P, Spadea A, D'Arco A, Pileri S, Leone G, Amadori S, Facchetti F; GIMEMAALWP (Gruppo Italiano Malattie EMatologiche dell'Adulto, Acute Leukemia Working Party). Blastic plasmacytoid dendritic cell neoplasm with leukemic presentation: an Italian multicenter study. Haematologica 2013;98:239246.

3. Dietrich $S$, Andrulis M, Hegenbart U, Schmitt T, Bellos F, Martens UM, Meissner J, Krämer $A, H o A D$, Dreger P. Blastic plasmacytoid dendritic cell neoplasia (BPDC) in elderly patients: results of a treatment algorithm employing allogeneic stem cell transplantation with moderately reduced conditioning intensity. Biol Blood Marrow Transplant 2011;17:1250-1254.
4. Kim HS, Kim HJ, Kim SH, Choi JY, Ko YH, Kim WS, Jung CW, Kim SJ. Clinical features and treatment outcomes of blastic plasmacytoid dendritic cell neoplasm: a single-center experience in Korea. Korean J Intern Med 2017;32:890-899.

5. Angelot-Delettre $F$, Roggy $A$, Frankel $A E$, Lamarthee $B$, Seilles $E$, Biichle $S$, Royer B, Deconinck E, Rowinsky EK, Brooks C, Bardet V, Benet B, Bennani $H$, Benseddik Z, Debliquis A, Lusina D, Roussel M, Solly F, Ticchioni M, Saas $P$, Garnache-Ottou F. In vivo and in vitro sensitivity of blastic plasmacytoid dendritic cell neoplasm to SL-401, an interleukin-3 receptor targeted biologic agent. Haematologica 2015;100:223-230.

6. Frankel A, Liu JS, Rizzieri D, Hogge D. Phase I clinical study of diphtheria toxin-interleukin 3 fusion protein in patients with acute myeloid leukemia and myelodysplasia. Leuk Lymphoma 2008;49:543-553.

7. Frankel $A E$, Woo JH, Ahn C, Pemmaraju N, Medeiros $B C$, Carraway $H E$, Frankfurt O, Forman SJ, Yang XA, Konopleva M, Garnache-Ottou F, AngelotDelettre F, Brooks C, Szarek M, Rowinsky E. Activity of SL-401, a targeted therapy directed to interleukin-3 receptor, in blastic plasmacytoid dendritic cell neoplasm patients. Blood 2014;124:385-392.

8. Feuring-Buske $M$, Frankel $A E$, Alexander $R L$, Gerhard $B$, Hogge DE. A diphtheria toxin-interleukin 3 fusion protein is cytotoxic to primitive acute myeloid leukemia progenitors but spares normal progenitors. Cancer Res 2002;62:1730-1736.

9. Aoki T, Suzuki R, Kuwatsuka $Y$, Kako S, Fujimoto K, Taguchi J, Kondo T, Ohata K, Ito T, Kamoda Y, Fukuda T, Ichinohe T, Takeuchi K, Izutsu K, Suzumiya J. Long-term survival following autologous and allogeneic stem cell transplantation for blastic plasmacytoid dendritic cell neoplasm. Blood 2015;125:3559-3562.

10. Roos-Weil D, Dietrich $S$, Boumendil A, Polge $E_{1}$ Bron D, Carreras $E_{\text {, Iriondo }}$ Atienza A, Arcese W, Beelen DW, Cornelissen JJ, Kröger N, Milone G, Rossi G, Jardin F, Peters C, Rocha V, Sureda A, Mohty M, Dreger P; European Group for Blood and Marrow Transplantation Lymphoma, Pediatric Diseases, and Acute Leukemia Working Parties. Stem cell transplantation can provide durable disease control in blastic plasmacytoid dendritic cell neoplasm: a retrospective study from the European Group for Blood and Marrow Transplantation. Blood 2013;121:440-446.

๑Copyright 2018 by Turkish Society of Hematology

Turkish Journal of Hematology, Published by Galenos Publishing House 